\title{
Sedimentology and depositional environment of the Lower Devonian Wapske Formation, Perth-Andover/Mount Carleton region, northwestern New Brunswick
}

\author{
Yaojun Han* and Ron K. Pickerill \\ Department of Geology, University of New Brunswick, Fredericton, New Brunswick E3B 5A3, Canada
}

Date Received March 6, 1995

Date Accepted June 2, 1995

\begin{abstract}
The Lower Devonian Wapske Formation of the Tobique Group in the Perth-Andover/Mount Carleton region, northwestern New Brunswick, forms part of the tectonostratigraphic Tobique Zone. In this area, the formation, 4000 to $9000 \mathrm{~m}$ thick, is interpreted to comprise seven regionally recognizable sedimentary facies. These are: conglomerate facies (Facies 1), massive and parallel-laminated sandstone facies (Facies 2), thin- to thick-bedded sandstone with minor mudstone interbeds and/or mud-capped facies (Facies 3), thin-bedded sandstone and mudstone facies (Facies 4), thin-bedded, graded, fine-grained sandstone facies (Facies 5), very thin-bedded, finegrained sandstone and silty mudstone facies (Facies 6), and thin- and medium-bedded siltstone and mudstone facies (Facies 7).

The absence of unequivocal shallow-water sedimentary structures, depositional cycles and in situ body fossils in these lithofacies and, instead, the presence of Bouma depositional sequences and deep-water trace-fossil associations, is supportive of a deep-marine origin (below storm-wave base) for the Wapske Formation in the study area. Accordingly, the facies are grouped into five facies associations interpreted to reflect a deep-marine fan system comprising distributary channels, depositional lobes, lobe or fan fringes, and interchannel areas associated with a basin plain.

Regional considerations suggest that the Wapske Formation records a transition from shallow-water marine, locally terrestrial, deposition to the east and southeast of the study area, to deep-water deposits, as described herein, to the west and northwest in the Perth-Andover/Mount Carleton region.
\end{abstract}

La formation du Dévonien inférieur Wapske du groupe de Tobique dans la région de Perth-Andover / du mont Carleton, dans le nord-ouest du Nouveau-Brunswick, fait partie de la zone tectonostratigraphique de Tobique. On interprète la formation de 4000 à $9000 \mathrm{~m}$ d'épaisseur de ce secteur comme un ensemble de sept faciès sédimentaires régionalement reconnaissables, notamment : un faciès de conglomérats (faciès 1); un faciès de grès massif en feuilles parallèles (faciès 2); un faciès de grès mince à épais avec petite quantité de mudstones interstratifiés ou couronné de boue (faciès 3 ); un faciès de grès et de mudstones finement stratifiés (faciès 4 ); un faciès de grès à grain fin grano-classé et très finement stratifié (faciès 5); un faciès de mudstones vaseux et de grès à grain fín très finement stratifiés (faciès 6); ainsi qu'un faciès de mudstones et de microgrès finement à moyennement stratifiés (faciès 7).

L'absence de structures sédimentaires univoques en eau peu profonde, de cycles sédimentaires et de fossiles massifs sur place à l'intérieur de ces lithofaciès et la présence, plutôt, des séquences sédimentaires de Bouma et d'associations d'empreintes fossiles en eau profonde appuient l'hypothèse d'une origine marine profonde (sous l'onde de tempête) dans le cas de la formation Wapske, dans le secteur étudié. En conséquence, les faciès sont regroupés en cinq associations de faciès qui, selon les interprétations, correspondent à un delta sous-marin profond constitué de canaux d'effluents, de lobes sédimentaires, de bordures en éventail ou lobées et de sections entre canaux associées à une plaine de bassin.

Des considérations régionales laissent supposer que la formation Wapske témoigne d'une transition d'une sédimentation en eau peu profonde, localement terrestre, à l'est et au sud-est du secteur étudié, à des dépôts en eau profonde, comme l'expliquent les présentes, à l'ouest et au nord-ouest de la région de Perth Andover / du mont Carleton.

[Traduit par la rédaction]

\section{INTRODUCTION}

New Brunswick has been divided into a number of preTaconian (Ordovician and older) tectonostratigraphic terranes of contrasting lithostratigraphic facies and tectonic styles and overlying cover sequences (Williams, 1983; Fyffe

* Present address: Department of Geology, University of Alberta, Edmonton, Alberta T6G 2E3, Canada and Fricker, 1987) (Fig. 1). The area located between PerthAndover in the southwest to the Mount Carleton Provincial Park in the northeast (Fig. 1), northwestern New Brunswick, is situated in the tectonostratigraphic Tobique Zone (St. Peter, 1978a, 1979; Pickerill, 1986, 1991; Wilson, 1990). The Tobique Zone is juxtaposed against the Chaleur and AroostookMatapédia zones to the north and west, respectively, along the Rocky Brook-Millstream Fault, and against the Miramichi Terrane to the east along the Woodstock and Portage Lakes- 


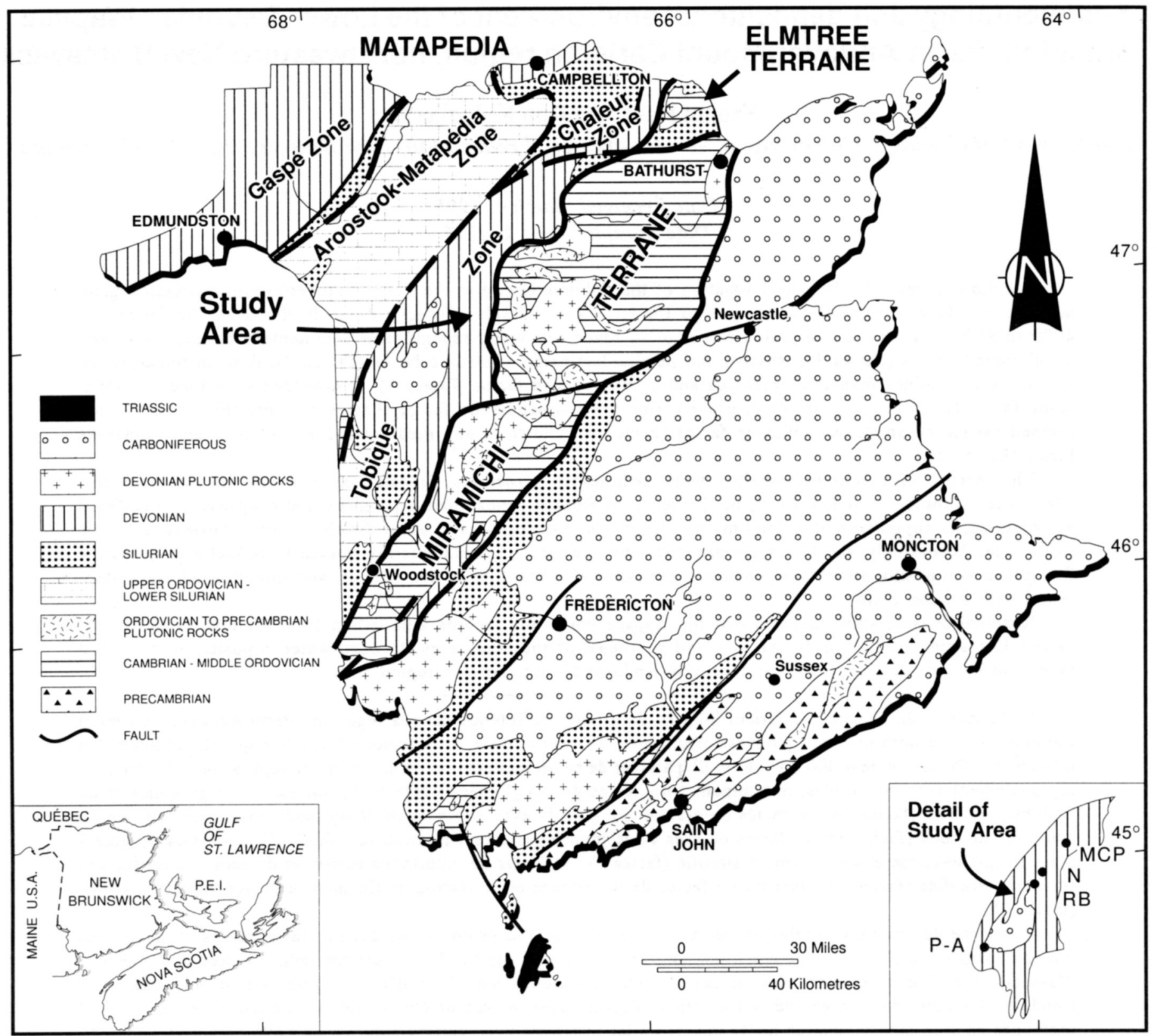

Fig. 1. Generalized tectonostratigraphic map of New Brunswick, eastern Canada, showing location of the study area (modified from Pickerill, 1986; Fyffe and Fricker, 1987; Wilson, 1990). P-A: Perth-Andover; RB: Riley Brook; N: Nictau; MCP: Mount Carleton Park.

Serpentine River fault systems. It comprises a northeasttrending belt of sedimentary and volcanic rocks of the surficially exposed Devonian Tobique Group, the subject of this contribution, and the Silurian Perham Group (Roy and Mencher, 1976; St. Peter, 1978a, b; Fyffe, 1982a, b). The Dalhousie Group, the lithostratigraphic equivalent of the Tobique Group, occurs only north of the Rocky Brook-Millstream Fault, whereas the Tobique Group is restricted to the area south of this fault (St. Peter, 1978b; Skinner, 1982; McCutcheon and Bevier, 1990). Strata of the Tobique Group, estimated to be between 4000 to $9000 \mathrm{~m}$ in thickness (St. Peter, 1979, 1982; Skinner, 1982), extend from near Woodstock in southwestern New Brunswick to the Upsalquitch Forks area in north-central New Brunswick (Wilson, 1990; McCutcheon and Bevier, 1990). This study focuses on the Lower Devonian (Lochkovian-
Pragian - equivalent, respectively, to Gedinnian-Siegenian) Wapske Formation of the Tobique Group, that crops out mainly in the Perth-Andover district and northeast of the Riley BrookNictau region (Fig. 2).

In these areas, continuous successions are rare and generally poorly exposed, the most continuous being located along roadside sections adjacent to the Tobique River in the Perth-Andover district on Routes 109 and 390, and in the Riley Brook to Mount Carleton Provincial Park area along provincial Routes 385 and 180 (Fig. 2). Grey, greenish grey and green siltstones interbedded with varying proportions of grey, greenish grey, brown, fine- to medium-grained sandstones and mudstones or shales are the most common lithotypes. No regional systematic lateral or vertical patterns in lithofacies distributions have yet been attempted, and given the gener- 


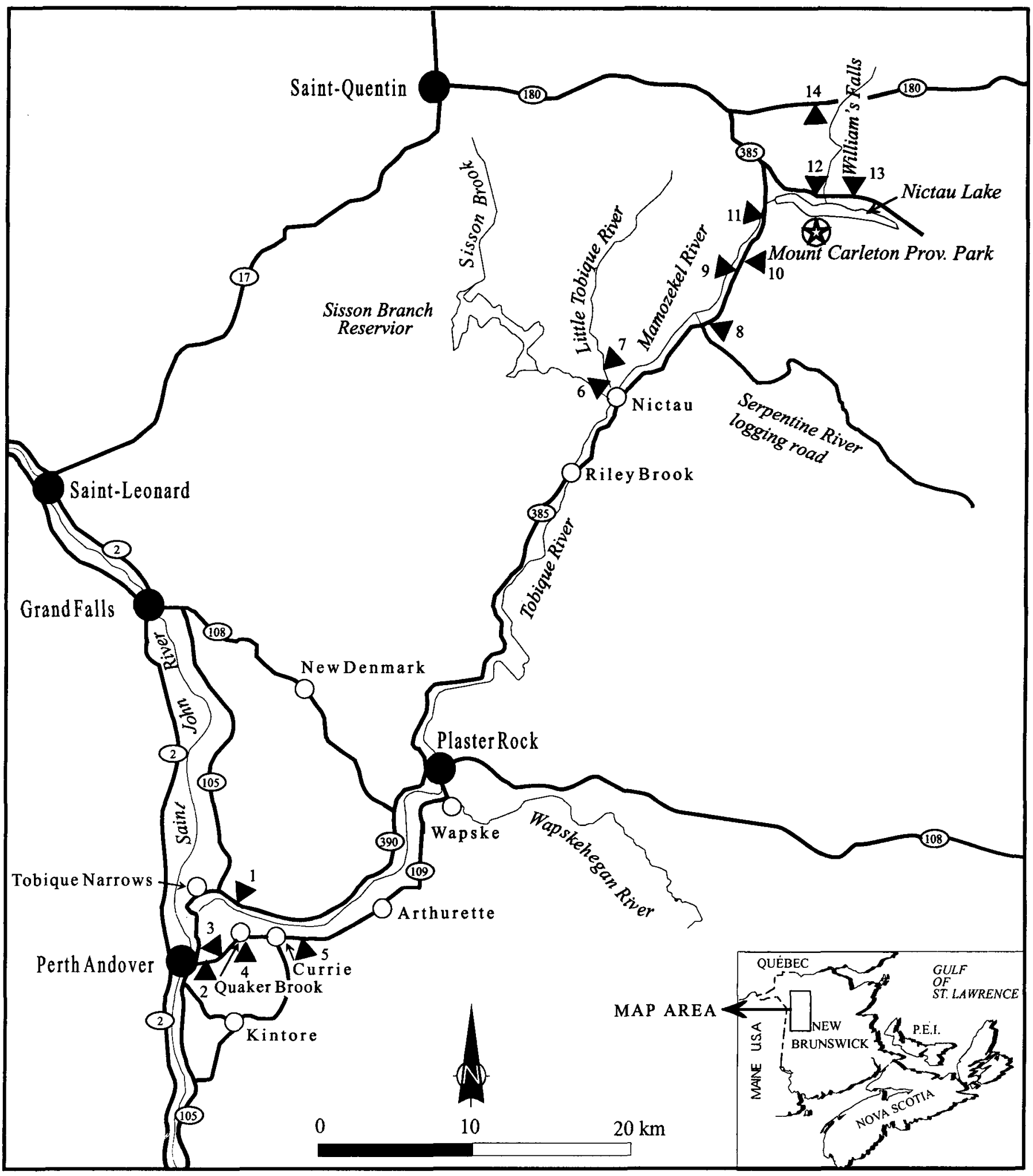

Fig. 2. Generalized location map of measured sections of the Wapske Formation (Lower Devonian), northwestern New Brunswick, eastern Canada. Numbers refer to sections: 1, Route 390, north bank of Tobique River in Perth-Andover, near Tobique Narrows; 2 , Route 109, $4.2 \mathrm{~km}$ west of the community of Quaker Brook, close to Perth; 3, Route 109, $3.1 \mathrm{~km}$ west of the community of Quaker Brook; 4, Route 109, community of Quaker Brook, beside a bridge; 5, Route 109, $1.6 \mathrm{~km}$ east of Currie; 6, $10 \mathrm{~km}$ northeast of the community of Riley Brook, outside Fraser Incorporated gate in Nictau; 7, $10 \mathrm{~km}$ northeast of the community of Riley Brook, inside Fraser Incorporated gate in Nictau; 8, Route 385, $24 \mathrm{~km}$ northeast of the community of Riley Brook; 9, Route 385, 30.2 km northeast of the community of Riley Brook; 10, Route $385,31.2 \mathrm{~km}$ northeast of the community of Riley Brook village; 11 , Route $385,33.1 \mathrm{~km}$ northeast of the community of Riley Brook; 12, North bank of Nictau Lake beside William's Falls in Mount Carleton Provincial Park; 13, North bank of Nictau Lake 2 km east of William's Falls in Mount Carleton Provincial Park; 14, Route 180, $9.1 \mathrm{~km}$ east of intersection of Routes 180 and 385. 
ally sporadic present-day outcrop distribution and the complex structure exhibited by the strata, such considerations are somewhat premature.

\section{Previous studies}

Lower Devonian strata of the Tobique Zone were initially informally divided into two to ten different unnamed map-units based on quarter-mile-scale mapping (Skinner, 1971, 1972; Constable, 1975a, b; Irrinki, 1977a, b, c, d, e, f). St. Peter (1978b) first proposed the stratigraphic descriptor Tobique Group for stratified Lower Devonian rocks from the head of the Wapskehegan River (locally known as the Wapske River) area. The group was originally proposed (St. Peter, 1978b) to consist of a basal volcanic-dominated Costigan Mountain Formation and a conformably overlying siliciclasticdominated Wapske Formation (Tables 1, 2). Lithologies of both formations are broadly similar but their relative proportions differ. Initially St. Peter (1978b) believed that the formations were probably conformable; however, faunal evidence later indicated that the Wapske Formation was, in part, intercalated and partially coeval with the Costigan Mountain Formation (St. Peter, 1979, 1981).

Palaeontological studies of the Tobique Group have documented a brachiopod-dominated Lochkovian-Pragian (Lower Devonian) shelly fauna (Boucot in St. Peter, 1978b, 1979, 1982; Skinner, 1982; Wilson, 1990; Boucot and Wilson, 1994), effectively giving both formations the same age. The Wapske Formation is, therefore, likely a lateral facies equivalent to the upper part of the Costigan Mountain Formation (Skinner, 1982) (Table 2). Since the establishment of the Tobique Group, both the Costigan Mountain and Wapske formations have been subdivided into several lithological units or assemblages (i.e., sedimentary, mafic and felsic volcanic rocks) that interdigitate and have no temporal stratigraphic significance (St. Peter, 1978b, 1979, 1981, 1982; Skinner, 1982; Irrinki and Crouse, 1986).

Several authors (e.g., St. Peter, 1978b, 1979, 1981, 1982; Skinner, 1982; Irrinki and Crouse, 1986; Wilson, 1990; Boucot and Wilson, 1994) have proposed a relatively shallow-marine, quiet-water depositional origin for the Wapske Formation essentially on the basis of its contained brachiopoddominated faunal communities. Fossil assemblages identified by Boucot (in St. Peter, 1978b) and Boucot and Wilson (1994) were considered representatives of Boucot's (1975) quiet-water Benthic Assemblage 3, typical of a mid-shelf environment below mean fair-weather wave base but above storm-wave base, and were designated as a MutationellaCommunity with rare components of Benthic Assemblage 4 and 5 communities. The depth range of Benthic Assemblage 3 has been recently suggested to occur from a minimum of 10 to $20 \mathrm{~m}$ to a maximum of $66 \mathrm{~m}$, with an average of 30 to $40 \mathrm{~m}$ (Brett et al., 1993).

However, an alternative scenario was envisaged by Pickerill (1986) who published an account of the Upper Silurian to Lower Devonian sequences underlying the Tobique Indian Reserve near the Perth-Andover district, and interpreted the Wapske Formation as having been deposited below storm-

Table 1. Summary of stratigraphy of the study area by different authors.

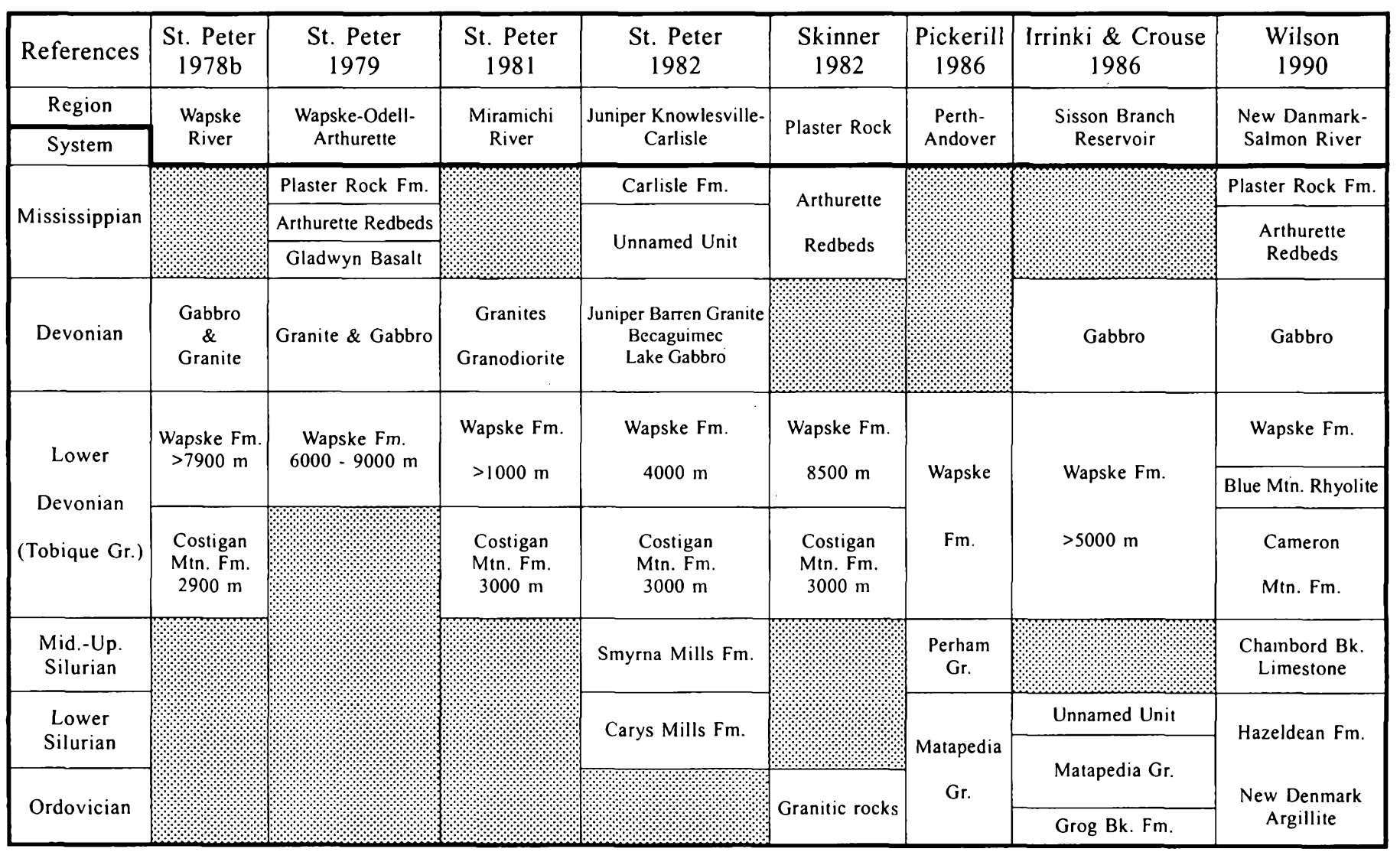


Table 2. Summary of lithostratigraphy and previously interpreted depositional environments of the Tobique Group. Numbers refer to: 1, Wilson, 1990. 2. Skinner, 1982. 3, Irrinki and Crouse, 1986. 4,5,6, and 7, St. Peter, 1978b, 1979, 1981 and 1982. 8, Pickerill, 1986. 9, Boucot and Wilson, 1994.

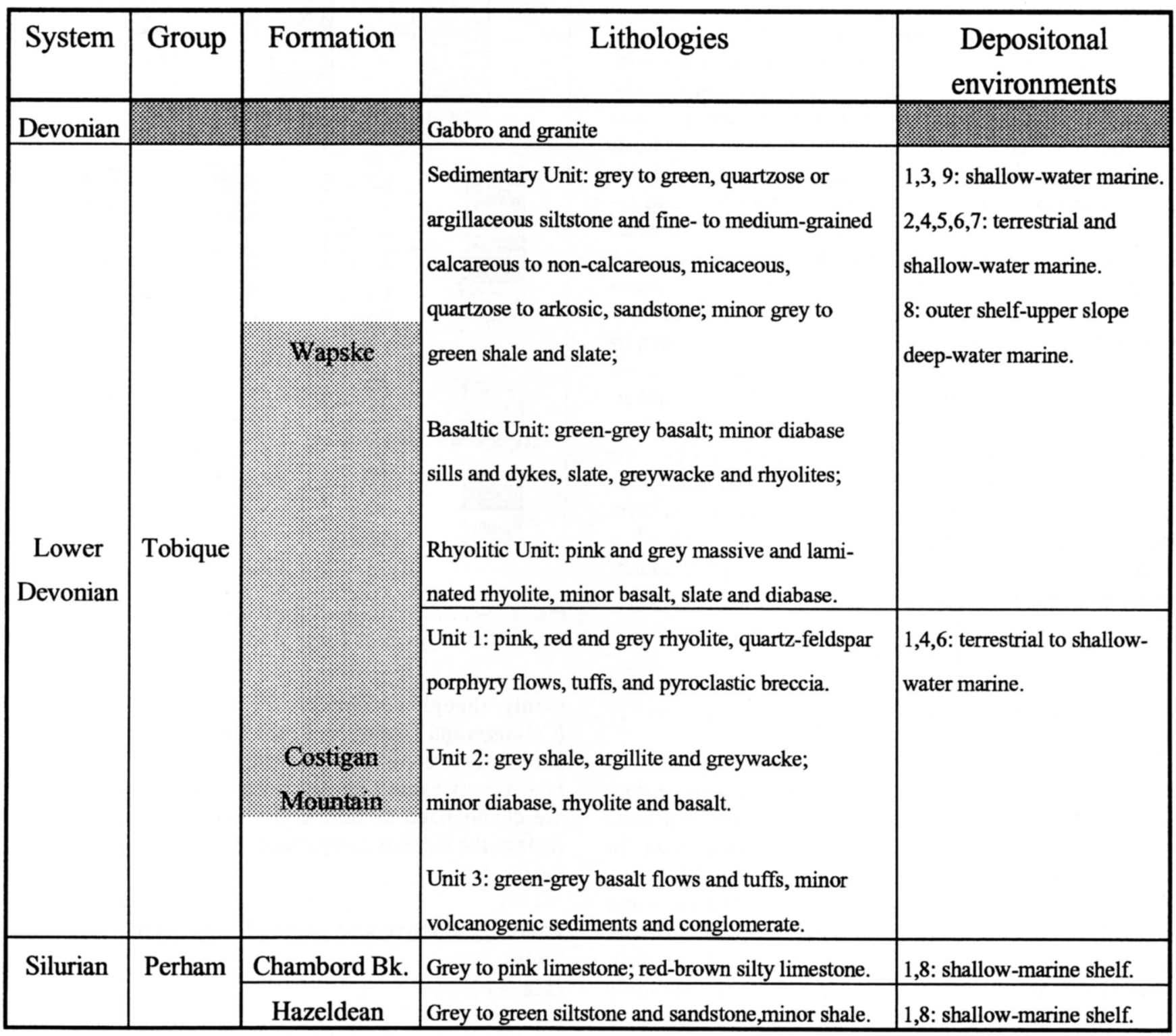

wave base in an outer shelf-upper slope depositional environment. In view of the varied interpretations with respect to its depositional environment, this contribution presents a sedimentological analysis of the Wapske Formation in the Perth-Andover/Mount Carleton region, the results of which contribute, in our opinion, to a better understanding of the much-debated depositional environment. The study is based essentially, though not exclusively so, on the more continuously well-exposed roadside and stream sections. The main emphasis will be on the recognized lithofacies and facies associations of the Wapske Formation, and the significance of its contained ichnofaunas, details of which are given in Pickerill (1991) and Han and Pickerill (1994a, b, c; 1995).

\section{Sedimentary faCies}

\section{Introduction}

The sedimentary facies recognized by us in the Wapske Formation in the Perth-Andover/Mount Carleton region are clearly dominated by turbidite deposits. The concept of turbidity currents has attracted widespread interest in geology, and much of the knowledge with respect to the sedimentary structures of turbidite deposits was initially summarized by Bouma (1962), who formulated the reknowned idealized Bouma sequence $T_{a}-T_{e}$. This sequence has provided the basis for a detailed discussion of turbidite facies and the introduction 
of deep-sea fan facies models (Walker, 1967, 1973, 1984, 1992; Normark, 1970; Mutti and Ricci Lucchi, 1972; Nelson and Kulm, 1973; Walker and Mutti, 1973; Ricci Lucchi, $1975 \mathrm{a}, \mathrm{b})$.

In turbidite and associated resedimented beds, the most important criteria used in facies subdivision are: grain size, bed thickness, sandstone/mudstone ratios, presence or absence of channels, sole marks, internal structures and textures, and palaeoecological indicators (Walker and Mutti, 1973). Based on these collective criteria, and observations from the northern Apennines, seven common turbidite facies (A through G) have been established (Mutti and Ricci Lucchi, 1972). The groupings of each of these various facies, or facies associations, can be assigned to specific depositional environments in an idealized submarine fan system. In this study, the facies classification first proposed by Mutti and Ricci Lucchi (1972), and subsequently modified by others (Walker and Mutti, 1973; Nilsen, 1984a, b; Walker, 1984,1992 ), is followed.

Seven sedimentary facies are recognized by us in the Wapske Formation (Figs. 3, 4; Table 3). They are individually distinguished by applying the aforementioned criteria (Walker and Mutti, 1973). Each facies is considered the product of a particular depositional process or, more particularly, combination of several processes.

\section{Description}

Facies 1: conglomerate facies (Fig. 4A)

The conglomerate facies consists of grey, poorly-sorted, internally structureless, matrix-supported polymictic conglomerates that only rarely crop out in the study area. In decreasing order of abundance, clasts comprise felsic and mafic volcanic rocks, chert, quartzite, quartzose arenite and slate, and are dispersed within a muddy and/or silty matrix. Most of the clasts are well rounded, spherical or subspherical, with diameters from 0.3 to $4.2 \mathrm{~cm}$. Clast axes are commonly parallel to bedding, resulting in crude parallel-stratification with no imbrication. Individual layers are 70 to $340 \mathrm{~cm}$ thick and, where observable, contacts between adjacent units are sharp, planar and non-erosive.

The absence of internal sedimentary structures and, instead, the presence of a massive muddy or silty matrix-supported fabric suggest deposition from mass flows (Fraser, 1989), in particular from debris flows. Debris flows represent a variety of sediment gravity flows, such as cohesive debris flows, density-modified grain flows and liquefied flows in which the flow is plastic (Shanmugam et al., 1994). In deep-water regimes such sediment gravity flows are com-

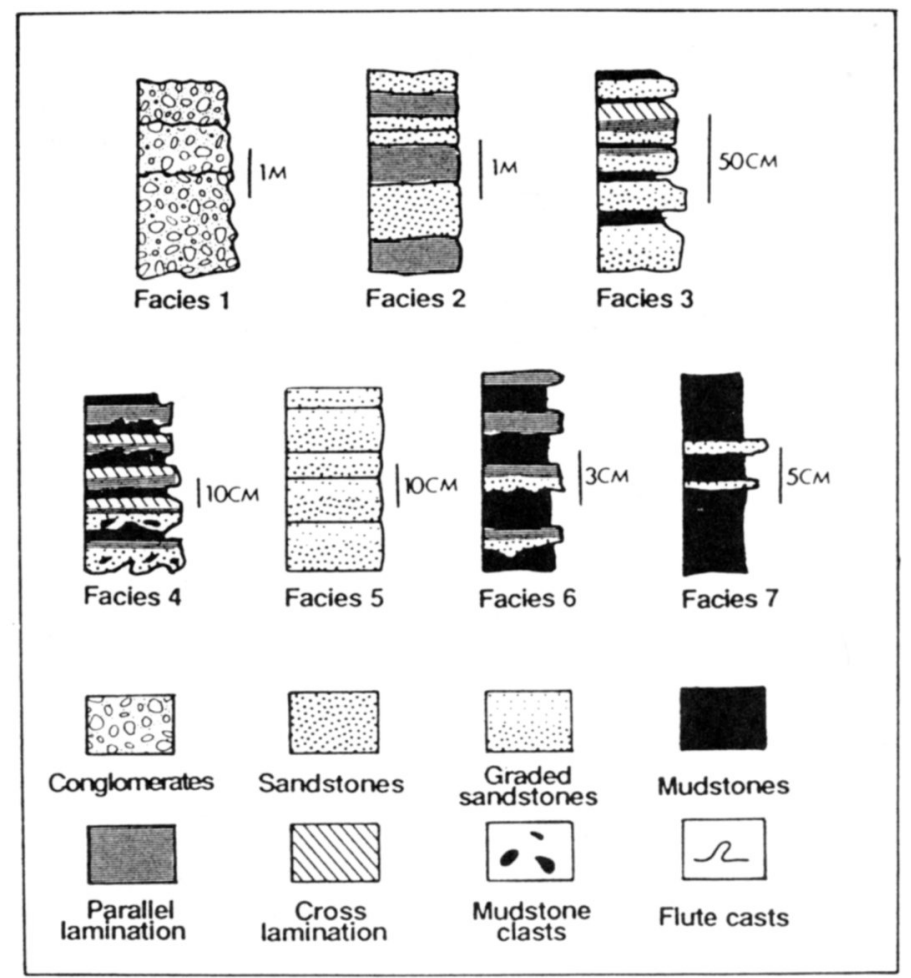

Fig. 3. Schematic vertical sequences, bedforms and sedimentary textures typical of facies 1 to 7 of the Wapske Formation.

monly, though not universally, associated with channels (Collinson and Thompson, 1982). Because of the poorly exposed nature of the conglomerate facies in the Wapske Formation, however, it cannot be determined whether the lithofacies are channelized or reflect sheet-like debris flows. Nevertheless, the facies is comparable to Walker and Mutti's (1973) Facies A.

\section{Facies 2: massive and parallel-laminated sandstone facies}

(Fig. 4B)

Fine- to coarse-grained, quartzose, micaceous, grey and greenish grey sandstones dominate this facies. Individual sandstone layers are thin- to thick-bedded (a few $\mathrm{cm}$ to $>100$ $\mathrm{cm}$ ) and amalgamated, with mudstone interbeds being absent. The strata are tabular and laterally continuous without significant change in lateral thickness. Internally, they are massive or parallel-laminated. There are no vertical changes in grain size within individual layers, nor are there any obvious trends in their vertical arrangement. The basal and upper contacts of individual units are sharp and planar without erosion or load cast structures.

Fig. 4. Lithofacies (A-G) and slump structures $(\mathrm{H})$ from the Wapske Formation. A. Facies 1: Conglomerate facies from section 13. B. Facies 2: Massive and parallel-laminated sandstone facies from section 2. C. Facies 3: Thin-to thick-bedded sandstone with minor mudstone interbeds and/or mud-capped top facies from section 8 . (Note the sequence is overturned, stratigraphic top to bottom). D. Facies 4: Thin-bedded sandstone and mudstone facies from section 5. E. Facies 5: Thin-bedded, graded, fine-grained sandstone facies from section 1. F. Facies 6: Very thin-bedded, fine-grained sandstone and silty mudstone facies from section 1. G. Facies 7: Thin- to medium-bedded siltstone and mudstone facies from section 4 . H. Slab showing intraformational slumps in finegrained sandstone from section 10 . Hammer $=28 \mathrm{~cm}$, Pen $=16 \mathrm{~cm}$, Ruler $=20 \mathrm{~cm} . \mathrm{H}, \times 1.3$. For locations see Figure 2 . 

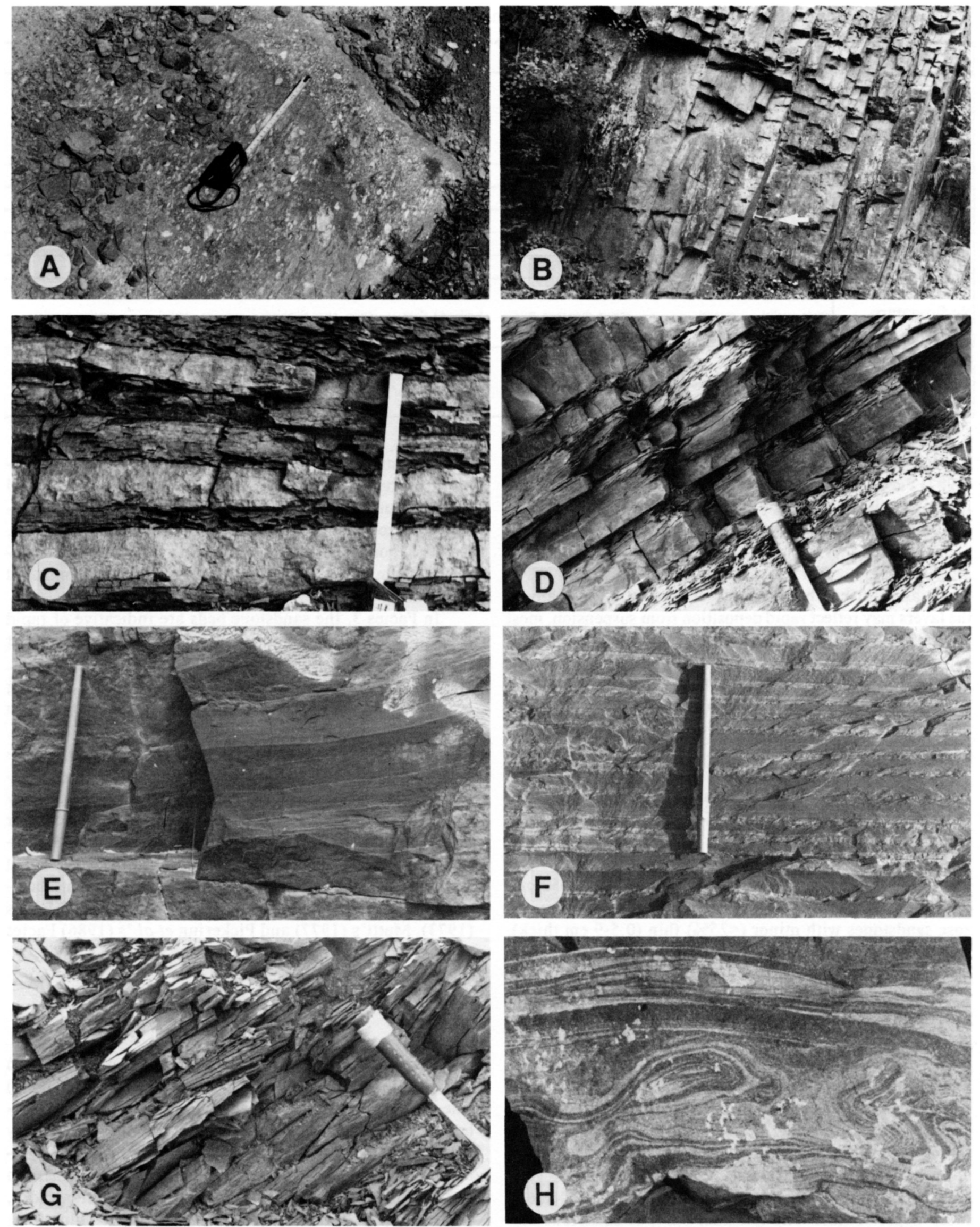
Table 3. Summary of lithofacies of the Wapske Formation and their essential characteristics.

\begin{tabular}{|c|c|c|c|c|c|c|c|}
\hline Lithofacies & 1 & 2 & 3 & 4 & 5 & 6 & 7 \\
\hline Main lithologies & $\begin{array}{l}\text { grey, matrix- } \\
\text { supported } \\
\text { conglomerates }\end{array}$ & $\begin{array}{l}\text { fine- to coarse- } \\
\text { grained sand- } \\
\text { stones without } \\
\text { mudstones }\end{array}$ & $\begin{array}{l}\text { fine- to medium-grained } \\
\text { sandstones with minor } \\
\text { thin mudstone interbeds, } \\
\text { typically with mud-top }\end{array}$ & $\begin{array}{l}\text { thinly interbedded } \\
\text { fine-grained sand- } \\
\text { stones \& mud- } \\
\text { stones }\end{array}$ & $\begin{array}{l}\text { graded fine-grained } \\
\text { sandstones or silt- } \\
\text { stones with rare } \\
\text { mudstones }\end{array}$ & $\begin{array}{l}\text { grey, fine- to very } \\
\text { fine-grained sand- } \\
\text { stones, sitstones \& } \\
\text { dark grey mudstones }\end{array}$ & $\begin{array}{l}\text { mudstones, silt- } \\
\text { stones with minor } \\
\text { thin sandstone } \\
\text { interbeds }\end{array}$ \\
\hline Bed thickness & $70-340 \mathrm{~cm}$ & $2->100 \mathrm{~cm}$ & $2.50 \mathrm{~cm}$ & $1-20 \mathrm{~cm}$ & $1.10 \mathrm{~cm}$ & $0.5-5 \mathrm{~cm}$ & $1.20 \mathrm{~cm}$ \\
\hline Sand/mud ratio & $1: 0$ & $1: 0$ & $1: 0.2$ & $1: 0.4$ & 1:0.2 & $1: 1$ & 1:5 \\
\hline Bed geometry & $\mathrm{NA}$ & tabular & tabular or lenticular & tabular & cabular & tabular or lencicular & tabular \\
\hline Bed base & $\mathrm{NA}$ & sharp & sharp & sharp or erosive & sharp and planar & sharp & sharp \\
\hline Bouma units & No & $\mathrm{Ta}, \mathrm{Tb}$ & Tae, abe, a-d & Tabc, bc, b-d, be & Ta; rare To-e, c-e, de & Tde, Tcee & Tde, $\mathrm{Te}$ \\
\hline $\begin{array}{l}\text { Sedimentary } \\
\text { structures }\end{array}$ & $\begin{array}{l}\text { crude parallel- } \\
\text { laminated }\end{array}$ & $\begin{array}{l}\text { massive or } \\
\text { parallel- } \\
\text { laminated }\end{array}$ & $\begin{array}{l}\text { parallel-, cross-laminated, } \\
\text { scours, flute casts, mud } \\
\text { clasts }\end{array}$ & $\begin{array}{l}\text { parallel., cross- } \\
\text { laminated, flute } \\
\text { casts, mud clasts }\end{array}$ & $\begin{array}{l}\text { graded, parallel-, } \\
\text { cross-, cross climbing- } \\
\text { laminated, flute casts }\end{array}$ & $\begin{array}{l}\text { massive, parallel- } \\
\text { laminated }\end{array}$ & $\begin{array}{l}\text { massive, parallel. } \\
\text { laminated }\end{array}$ \\
\hline $\begin{array}{l}\text { Interpreted } \\
\text { depositional } \\
\text { processes }\end{array}$ & $\begin{array}{l}\text { mass flow, } \\
\text { especially } \\
\text { debris flows }\end{array}$ & $\begin{array}{l}\text { high-density } \\
\text { turbidity currents }\end{array}$ & $\begin{array}{l}\text { turbidity currents \& } \\
\text { bemipelagic }\end{array}$ & $\begin{array}{l}\text { low-density } \\
\text { turbidity } \\
\text { currents } \\
\end{array}$ & $\begin{array}{l}\text { high-density } \\
\text { gravity \& traction } \\
\text { nows } \\
\end{array}$ & $\begin{array}{l}\text { low-density } \\
\text { turbidity aurrents } \\
\& \text { bemipelagic }\end{array}$ & $\begin{array}{l}\text { bemipelagic, pelagic } \\
\text { \& low-density } \\
\text { turbidity currents }\end{array}$ \\
\hline
\end{tabular}

In Walker and Mutti's (1973) and Howell and Normark's (1982) Facies B and Walker's (1984) "massive sandstones" facies, individual sandstone beds are much thicker than those described herein, ranging from about $50 \mathrm{~cm}$ to many metres. Scour and channel features, dish structures, and mud chips are also common characters, whereas they are absent in Facies 2 as described herein. Lack of lamination in many of the layers may reflect rapid deposition from suspension, most probably by the deceleration of a heavily sediment-laden current (Collinson and Thompson, 1982; Pickering et al., 1986). Alternatively, the parallel-laminated sandstones may be the result of "freezing" of successively generated, thinner, traction carpets at the base of a high-concentration turbidity current (cf. Pickering et al., 1986).

Facies 3: thin- to thick-bedded sandstone with minor mudstone interbeds and/or mud-capped facies

(Fig. 4C)

This facies consists of thin- to thick-bedded $(2-50 \mathrm{~cm}$, commonly $6-10 \mathrm{~cm}$ thick), fine- to medium-grained, quartzose sandstones with minor $(<25 \%)$ thin $(0.5-9 \mathrm{~cm}$ thick), silty mudstone interbeds. Typically, individual grey and brown sandstone beds pass upward into dark grey mudstones or silty mudstones as a final cap to the top of each event unit. These mudstones tend to split into very thin laminae or small chips. Rarely, they can be observed to comprise distinctive layers possessing a clearly defined and sharp, rather than gradational, boundary with the underlying sandstone bed. The mudstones are laterally continuous, more rarely discontinuous and lenticular. As a consequence, associated sandstones also exhibit lateral changes in thickness. The nature of the upper and lower contacts of sandstone layers is variable. Most, however, have a sharp lower and moderately sharp upper contact. The irregular bases of sandstone layers may exhibit scours, and irregular flute marks and mudstone clasts may be included in their lower portions. Typically, within a single unit, the fine-grained sandstone por- tions are much thicker than the overlying mudstones. Internally, individual sandstone layers are normally graded and massive but may possess cross-laminated and, more typically, horizontally laminated upper horizons; less commonly, massive, normally graded layers pass vertically into horizontally laminated, cross-laminated and parallel-laminated horizons.

In Facies 3, the sandstone beds are indicative of rapid deposition within an otherwise quiet-water environment. Most sandstone beds of this facies are interpreted to represent, respectively as described above, Bouma $T_{a e}, T_{a b e}$ and $T_{a-d}$ sequences. The Bouma sequences, vertical changes of grain size and mud-capped tops are indicative of waning currents. The medium- to thick-bedded sandstones and the thin-bedded sandstones are interpreted to represent deposition from high- and low-concentration turbidity currents respectively (cf. Pickering et al., 1986). The interbedded mudstones or mud-cap laminae in the sandstones may have been deposited from pelagic/hemipelagic suspension or from suspended finer grained sediments carried by the turbidity currents themselves. This facies is very similar to Walker and Mutti's (1973), Mutti's (1977) and Pickering et al.'s (1986) Facies C.

\section{Facies 4: thin-bedded sandstone and mudstone facies (Fig. 4D)}

This facies consists of mainly grey (weathered brown or buff), thin-bedded (1-20 cm, commonly $2-8 \mathrm{~cm}$ thick) fine- to medium-grained sandstones and dark grey, thinbedded (1-6 cm, commonly $2 \mathrm{~cm}$ thick) mudstones or silty mudstones. In individual successions, sandstones are typically and commonly thicker than or of equal thickness to the mudstones. Sandstones are massive, normally graded, parallel- or cross-laminated and in various combinations. Mudstones are very soft and fissile, and appear massive. Bed thickness is laterally consistent on outcrop scale. Both planar and irregular bases of sandstone layers are present, 
the latter exhibiting scours and small-scale flute casts. The upper boundaries of sandstone layers are tabular and sharp.

The facies is similar to Mutti and Ricci Lucchi's (1972) and Walker and Mutti's (1973) Facies D strata, equivalent to the traditional "distal turbidites" of Walker (1967). The most common Bouma sequences exhibited by the sandstones are, in decreasing order of relative abundance, $T_{a-c}, T_{b c}$, $\mathrm{T}_{\mathrm{b}-\mathrm{d}}$ and $\mathrm{T}_{\mathrm{b}-\mathrm{e}}$. Associated mudstones are presumably a result of pelagic/hemipelagic deposition or may be the final depositional products of turbidity currents that contained abundant fine-grained material.

Facies 5: thin-bedded, graded, fine-grained sandstone facies

(Fig. 4E)

This facies consists of thin-bedded, normally graded, fine-grained sandstones or coarse-grained siltstones with rare or typically no mudstone interbeds. The grey, greenish grey sandstones and siltstones are 1 to $10 \mathrm{~cm}$ (commonly 2-8 $\mathrm{cm}$ ) in thickness, which remains laterally constant across exposures. On weathered surfaces, the colour changes upward from brown to grey. Vertical changes in grain size are typically gradual, though may be relatively abrupt, upper layers being comprised of thin, dark grey, muddy sandstones or siltstones. Lower boundaries are sharp and planar. Amalgamation is very common resulting in a "thick-bedded" appearance. The most common internal structures within individual layers, in addition to grading, are, in vertical sequence, parallel-, cross- and/or climbing-ripple lamination.

The sharp bases, clear definition and sequence of internal structures within the coarser layers suggest that strata of Facies 5 represent relatively sudden turbidite deposition superimposed upon a background of quieter, more constant sedimentation of the, albeit rare, finer grained and darker pelagic or hemipelagic mudstone layers. With respect to the idealized Bouma sequence, $T_{a}$ units are the most common, with fewer examples of $T_{b-e}, T_{c-e}$ and $T_{d e}$ divisions. Facies 5 is similar to Mutti and Ricci Lucci's (1972) and Walker and Mutti's (1973) Facies E.

Facies 6: very thin-bedded, fine-grained sandstone and silty mudstone facies

(Fig. 4F)

This facies comprises very thin interbeds of fine- to very fine-grained sandstones or siltstones and silty mudstones. The dark grey, silty mudstone layers are 2 to $5 \mathrm{~cm}$ thick, and the light grey, fine-grained sandstone beds 0.1 to $2 \mathrm{~cm}$ thick. Thickness of individual sandstone and mudstone beds is typically consistent but can vary slightly over several metres of exposed sections. On weathered surfaces, the layers commonly show a distinct colour gradation from dark grey at the base through greenish grey to light grey at the top. The colour alternation gives the facies a "varved" or "pin-stripe" (Pickerill, 1986) appearance. The sandstone beds are typically sharp based, planar and non-erosive, more rarely irregular and erosive. Most beds are parallel-laminated and/ or parallel-passing vertically into cross-laminated horizons, but may be massive. The grading is normal and generally gradual, though relatively abrupt transitions from sandstone to mudstone may occur. No consistent vertical patterns with respect to grain size, bed thickness and internal sedimentary structures can be discerned.

This facies is very similar to the thin-bedded siltstone turbidites of upper basin-slope deposits of the Varanger Peninsula, Norway (Pickering, 1982a, 1984; Pickering et al., 1986) and mid-slope basin deposits of the Rangitata Orogen, New Zealand (Carter et al., 1978). The sharp contacts suggest suddenly increasing and waning high discharge episodes, like slump-triggered turbidity currents, rather than gradual depositional processes. The interpreted Bouma divisions $\left(T_{d e}, T_{c-e}\right)$, reduced grain sizes and bed thicknesses, absence of directional sole marks and mostly non-erosive bases suggest deposition from low-density, low-velocity turbidity currents and associated suspension processes (Pickering, 1982a). There is no corresponding facies in Mutti and Ricci Lucchi's (1972) and Walker and Mutti's (1973) facies model of submarine fan deposits.

\section{Facies 7: thin- and medium-bedded siltstone and mudstone facies \\ (Fig. 4G)}

This facies consists of micaceous, silty mudstones and/ or very fine-grained, muddy siltstones with rare thin-bedded, fine-grained sandstone or, dominantly, siltstone interbeds. The mudstones and siltstones are 1 to $20 \mathrm{~cm}$ (commonly 2$5 \mathrm{~cm}$ ) thick while the sandstones are 0.5 to $10 \mathrm{~cm}$ thick. The grey (weathered brown or maroon), muddy siltstone and silty mudstone layers are of constant thickness laterally. In most cases, they are easily weathered to mud chips. The coarse-grained siltstones or fine-grained sandstones are rare, occurring as either laminae or extremely thin but distinct layers that possess planar and non-erosive bases.

Internally, the coarse-grained siltstones and/or fine-grained sandstones are typically massive or parallel laminated, and the mudstones are essentially massive. Collectively, this facies is similar to Facies G of Mutti and Ricci Lucchi (1972) and Walker and Mutti (1973), that may involve all, or a combination of, normal pelagic/hemipelagic deposition from suspension in association with nepheloid layers, deposition from dilute turbidity currents, or reworking by contour currents (Walker and Mutti, 1973).

\section{Facies associations}

\section{AND DEPOSITIONAL ENVIRONMENTS}

Facies associations, as defined by Reading (1986), are groups of facies that occur together and are considered to be genetically or environmentally related. Fourteen stratigraphic sections (mainly in the Perth-Andover district and to the northeast of the Riley Brook-Nictau region - see Fig. 2 ) were logged in detail for facies association analysis. These sections were chosen because they are relatively continuous, easily accessible, better exposed and exhibit vertical 
facies variations. Bouma sequences (Bouma, 1962) and other descriptive categories (i.e., Mutti and Ricci Lucchi, 1972; Walker and Mutti, 1973; Walker, 1984, 1992) were used in describing and classifying the strata. Major features of the facies associations are summarized in Table 4.

\section{Facies Association 1}

This occurs on the north bank of Nictau Lake in sections 12 and 13 (Figs. 2, 4A).

Thick-bedded conglomerates are the only lithotype (Facies 1). The geometry of the conglomerates, their relationship with adjacent beds, and lateral and vertical variations in bed thickness cannot be ascertained due to poor exposure. Stratigraphically, however, they are exposed between outcrops of thin-bedded, fine-grained sandstones or coarse-grained siltstones of Facies 5.

The coarse grain size, bed thickness and limited exposure and geographic distribution are suggestive of a distributary channel setting dominated by debris flows and/or turbidity currents, though the precise depositional regime cannot be ascertained.

\section{Facies Association 2}

The best exposed sections of Facies Association 2 occur at locations 2, 3 and 14 and parts of sections 1 and 8 (Figs. $2,5 B)$.
This facies association comprises medium- to thick-bedded, medium-grained sandstones (Facies 2 and 3 ) in association with thin-bedded, graded, commonly amalgamated sandstones (Facies 5) and rare thin- to medium-bedded, fine-grained sandstones and mudstones (Facies 4). All beds are essentially laterally continuous on outcrop scale, with only rare examples of lateral discontinuity. There is no evidence of channelized deposition. Most beds are parallel-sided and exhibit high sandstone/mudstone ratios. Flute casts and ripup mud clasts may occur on the soles of some sandstone beds. $\mathrm{T}_{\mathrm{a}-\mathrm{e}}$ and $\mathrm{T}_{\mathrm{b}-\mathrm{e}}$ are the most commonly observed Bouma sequences.

The association exhibits crudely developed thickeningand coarsening-upward cycles. Such cyclical sequences, with generally high sandstone/mudstone ratios and laterally continuous beds most probably reflect active turbidity current deposition in depositional lobes (Mutti and Ricci Lucchi, 1972; Walker and Mutti, 1973; Mutti and Normark, 1987). In prograding fans, depositional lobes aggrade until deposition switches to another part of the fan and commences to build another lobe (Walker and Mutti, 1973). Each lobe is characterized by a thickening- and coarsening-upward sequence as a result of such aggradation (Walker and Mutti, 1973). In the Wapske Formation, this facies association probably reflects switching of such depositional lobes in a mid-outer fan regime, with possible distributary channel deposits represented by thick-bedded sandstones. Waning and relatively dilute turbidity currents are interpreted to have been responsible

Table 4. Main characteristics of facies associations of the Wapske Formation described herein.

\begin{tabular}{|l|l|l|l|l|l|}
\hline $\begin{array}{l}\text { Facies } \\
\text { Association }\end{array}$ & \multicolumn{1}{|c|}{1} & 2 & 3 & 4 & \multicolumn{1}{|c|}{5} \\
\hline $\begin{array}{l}\text { Main Facies } \\
\text { Minor Facies }\end{array}$ & Facies 1 & $\begin{array}{l}\text { Facies 2 \& 3 } \\
\text { Facies 4 \& 5 }\end{array}$ & $\begin{array}{l}\text { Facies 4 } \\
\text { Facies 5 \& 7 }\end{array}$ & $\begin{array}{l}\text { Facies 4 \& 5 } \\
\text { Facies 2, 6 \& 7 }\end{array}$ & $\begin{array}{l}\text { Facies 7 } \\
\text { Facies 3 \& 4 }\end{array}$ \\
\hline $\begin{array}{l}\text { Vertical } \\
\text { Upward } \\
\text { Tendency }\end{array}$ & none & thickening & crude thinning & thinning & none \\
\hline $\begin{array}{l}\text { Sand/Mud Ratio } \\
\text { Lateral Continuity } \\
\text { Bouma Units }\end{array}$ & $\begin{array}{l}\text { very high } \\
\text { poor }\end{array}$ & $\begin{array}{l}\text { hagh } \\
\text { good } \\
\text { Ta-e, b-e }\end{array}$ & $\begin{array}{l}\text { low-medium } \\
\text { good } \\
\text { Tb-e, c-e, de }\end{array}$ & $\begin{array}{l}\text { low } \\
\text { excellent } \\
\text { Tb-d, b-e, ab }\end{array}$ & $\begin{array}{l}\text { low } \\
\text { excellent } \\
\text { Tb-e, de }\end{array}$ \\
\hline $\begin{array}{l}\text { Depositional } \\
\text { Processes }\end{array}$ & $\begin{array}{l}\text { debris flows } \\
\text { \& turbidity } \\
\text { currents }\end{array}$ & $\begin{array}{l}\text { turbidity } \\
\text { currents }\end{array}$ & $\begin{array}{l}\text { dilute turbidity } \\
\text { currents \& } \\
\text { hemipelagic }\end{array}$ & $\begin{array}{l}\text { dilute turbidity } \\
\text { currents \& } \\
\text { hemipelagic }\end{array}$ & $\begin{array}{l}\text { hemipelagic } \\
\text { \& turbidity } \\
\text { currents }\end{array}$ \\
\hline $\begin{array}{l}\text { Interpreted } \\
\text { Depositional } \\
\text { Environments }\end{array}$ & $\begin{array}{l}\text { distributary } \\
\text { channels }\end{array}$ & $\begin{array}{l}\text { lobe in mid- } \\
\text { outer fan }\end{array}$ & lobe fringe & $\begin{array}{l}\text { interchannel } \\
\text { area \& partial } \\
\text { basin plain }\end{array}$ & $\begin{array}{l}\text { basinplain } \\
\text { \& distal } \\
\text { outer fan }\end{array}$ \\
\hline
\end{tabular}

Fig. 5. Facies associations of the Wapske Formation. A. Facies Association 5 representing basin plain and partial outer-fan deposits from section 4. B. Facies Association 2 representing lobe deposits from section 8 . The thin-bedded sandstones and mudstones on the upper part of the figure (above dashed line) represent lobe fringe deposits of Facies Association 3. C. Photomosaic of facies Association 4 representing interchannel deposits from section 9 . Note the thinning upward tendency of individual sequences (arrowed). Hammer in $A=28 \mathrm{~cm}$, Ruler (arrowed in B and $\mathrm{C}$ ) $=100 \mathrm{~cm}$. Location of sections is given in Figure 2. 

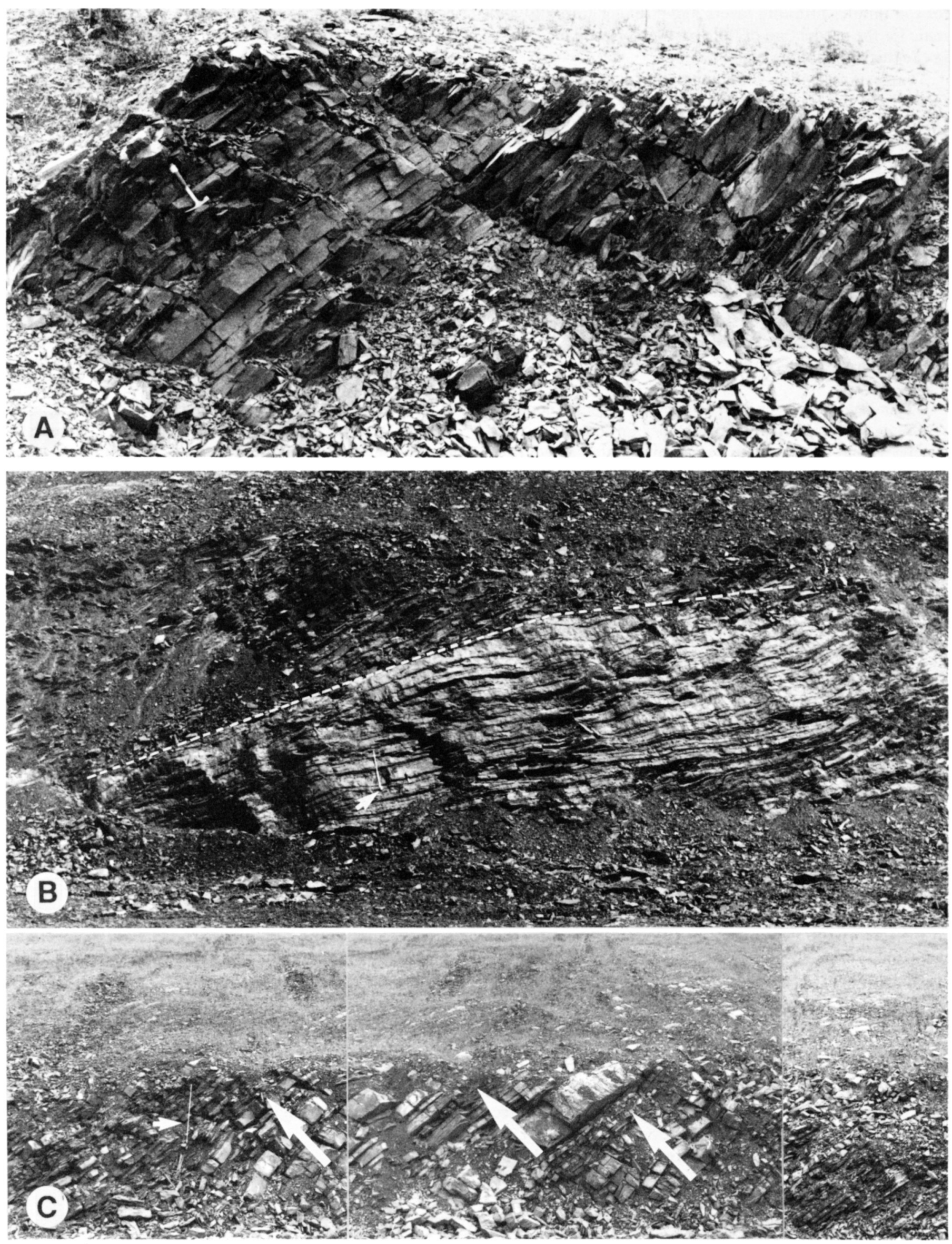
for the thinner turbidite layers and stronger turbidity currents for the production of flute casts and rip-up mud clasts in the thicker turbidite beds.

Facies Association 2 is comparable to depositional lobe facies from the Raeberry Unit A Member of the Southern Uplands of Scotland (Kemp, 1987), the Kongsfjord Formation of Norway (Pickering, 1981, 1985), the lobe VIII of the Cengio Sandstone member of the Tertiary Piedmont Basin of Italy (Cazzola et al., 1985), and is also comparable to Mutti and Ricci Lucchi's (1972) Facies C and D turbidites with subordinate Facies $\mathrm{E}$.

\section{Facies Association 3}

This association is best represented in section 5 and parts of section 8. It is also observed along Route 385 at the intersection with the Serpentine River logging road (Figs. $2,6)$.

Thin-bedded sandstones and mudstones (Facies 4) dominate this facies association with mudstones up to $5.36 \mathrm{~m}$ thick (Facies 7) and thin, graded, commonly amalgamated, finegrained sandstones or coarse-grained siltstones up to $5 \mathrm{~m}$ thick (Facies 5). The interbedded sandstones and mudstones show a broad thinning upward tendency (cf. Howell and Normark, 1982) and a corresponding decrease in sandstone/ mudstone ratios. The sandstones exhibit good lateral continuity and small-scale scouring. The sequences exhibit low to medium sand/mud ratios. Most sandstone or siltstone beds possess $T_{b-e}, T_{c-e}$ and $T_{d e}$ Bouma sequences. Turbidity currents and pelagic/hemipelagic suspension processes are the main depositional mechanisms.

Facies Association 3 from the Wapske Formation displays many of the characteristics regarded as typical of outer fan lobe fringe facies described from the Hecho Group of Spain (Mutti, 1977) and the Kongsfjord Formation of Norway (Pickering, 1985). The most similar characters are in the cyclical vertical variations of the sandstone/mudstone ratios and in the thickness of the sandstone beds in these facies associations. In the Wapske Formation, facies association 3, similarly interpreted as a lobe fringe facies, crops out rarely in association with thicker bedded and coarser grained facies 2 and 3 as described herein. This is similar to the lobe fringe facies described by Mutti (1977) where comparable thicker bedded lithofacies also occur, interpreted by Mutti (1977), as indeed herein, as representative facies of prograding lobes.

\section{Facies Association 4}

This is the most commonly occurring facies association in the selected sections. Such successions crop out at sections 6, 9, 10 and 11 and parts of section 1 (Figs. 2, 5C).

Thin-bedded, fine-grained, normally graded sandstones (Facies 5) and thinly interbedded sandstones and mudstones (Facies 4) are the most common lithofacies. Amalgamation of sandstones is common. The facies association also includes mudstones with rare thin sandstone interbeds (Facies 7) or very thinly interbedded "pin-stripe" sequences (Facies
6) or rare medium- to thick-bedded sandstones (Facies 2). All layers are laterally extensive. The sequences possess low sandstone/mudstone ratios. Intraformational slumps and slides are present but rare. The most common Bouma sequences are $\mathrm{T}_{\mathrm{b}-\mathrm{d}}, \mathrm{T}_{\mathrm{b}-\mathrm{e}}$ and, more rarely, $\mathrm{T}_{\mathrm{a}-\mathrm{e}}$. Individual successions commonly exhibit a tendency to thin- and fine-upward. Also present, however, are minor thickening-upward cycles.

The facies association is interpreted to represent turbidity current and/or hemipelagic deposition in interchannel regions and possibly even partially on a basin plain. This interpretation is based on its upward-thinning tendency, presence of laterally extensive thin-bedded sandstone layers, internal sedimentary structures, grain sizes and wide geographic distribution (cf. Walker and Mutti, 1973; Carter et al., 1978; Pickering, 1982b). The interpreted interchannel deposits are, for example, extremely comparable to those described from the Kongsfjord Formation of northern Norway (Pickering, 1982b) and Eocene Butano submarine fan (Nilsen, 1985). Though slumps and slides are present in the Wapske Formation, lateral channel margin and levee sliding, common in the aforementioned sequences, cannot be recognized. The isolated sandstone layers (Facies 2), that are both thicker and coarser than the surrounding beds, are sheet-like and interpreted as prograding lobes, because no evidence of channeling is found (cf. Pickering, 1982b).

\section{Facies Association 5}

Facies Association 5 is represented by sections 4 and 7 (Figs. 2, 5A).

Thin-bedded mudstones and silty mudstones dominate with rare thin, fine-grained sandstone interbeds (Facies 7). Thin-bedded, fine-grained, mud-capped sandstones (Facies 3 ) and thinly interbedded, fine-grained sandstones and mudstones (Facies 4) may also be present. The association exhibits low sandstone/mudstone ratios and no recognizable depositional cycles. Individual beds are laterally continuous on outcrop scale. Most sandstones exhibit $\mathrm{T}_{b-e}$ and $\mathrm{T}_{\mathrm{de}}$ Bouma sequences.

Facies Association 5 is interpreted to represent deposition dominated by hemipelagic sediments and sediments deposited by dilute turbidity currents in a basin plain or distal area of an outer fan. As noted previously, the intercalated thin-bedded, fine-grained sandstones are most likely the product of turbidity currents, and the sandstones, with mud-capped tops, of dilute and waning turbidity currents. The association is comparable to the deep-sea plain association from the Val Luretta Formation of the northern Appennines (Mutti and Ricci Lucchi, 1972) and from the Ohau Ski Basin, Rangitata Orogen of New Zealand (Carter et al., 1978).

\section{Depositional environments - SUMMARY AND DISCUSSION}

Pickerill $(1986,1991)$, based on the sequences exposed in the Perth-Andover district and the Riley Brook-Nictau 


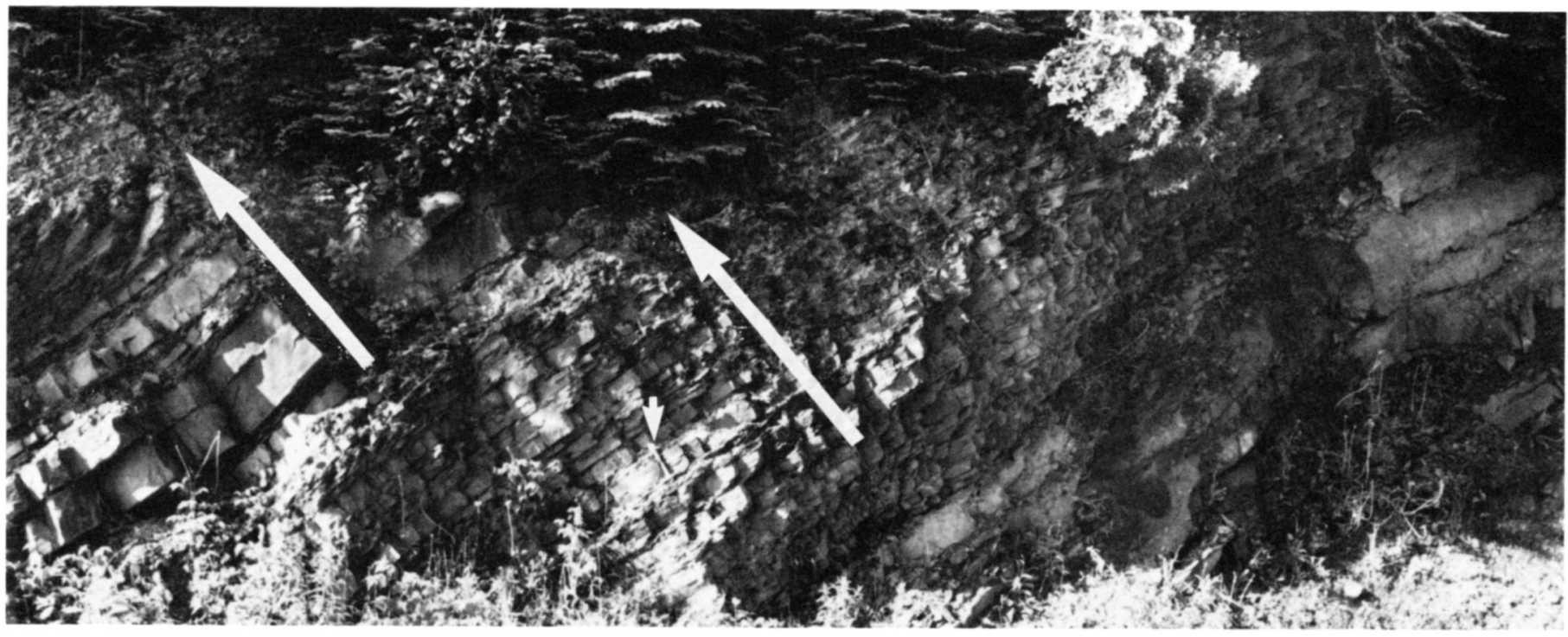

Fig. 6. Facies Association 3 representing lobe fringe deposits from section 5. Note the thinning-upward tendency of individual sequences (arrowed). Hammer (at mid centre-arrowed) $=28 \mathrm{~cm}$. Location of section is given in Figure 2 .

region, suggested that strata of the Wapske Formation represented deep-marine strata that were deposited below stormwave base in an outer shelf/upper slope environment. Sandstone and siltstone beds were interpreted to have been deposited from turbidity currents, and interbedded silty mudstones from suspension by dilute turbidity currents and/or by hemipelagic settling, though he did not identify any particular subenvironments.

An important consideration with respect to the depositional environment of the sections discussed herein is the absence of primary sedimentary structures suggestive of a shallow-water marine scenario. As previously noted, most other authors to have investigated the Tobique Group, more recently particularly Boucot and Wilson (1994), have assigned the faunal components essentially to Benthic Assemblage 3. Although absolute water depths are difficult to assess, average values for Benthic Assemblage 3, as reviewed by Brett et al. (1993), are approximately 30 to $40 \mathrm{~m}$, that is, well above mean storm-wave base. Yet in the Wapske Formation in the Perth-Andover/Mount Carleton region there is no evidence in the strata, such as hummocky cross-stratification, multidirectional sole markings, pot and gutter casts, discrete shell and lag deposits, etc. (see Brett et al., 1993), to indicate deposition above storm-wave base. On the contrary, sedimentological evidence, as described herein, suggests deposition below storm-wave base, average values of which, according to Pickerill and Brenchley (1991), are 100 m.

Additionally, the presence of soft-sediment deformation and intraformational slump folding in the sandstones and siltstones (Fig. $4 \mathrm{H}$ ) is more consistent with deposition in a deep-water setting (see also Pickerill, 1986). Finally, though body fossils are rare in the examined sections, trace fossils are relatively well preserved, abundant and diverse. Collectively, these trace fossils are representatives of the deepwater Nereites ichnofacies of Seilacher (1967) and are char- acterized by a high diversity ( 23 ichnogenera and 41 ichnospecies). Most trace fossils in the sequence are shallow, horizontal structures reflecting grazing, sediment-mining and farming activities produced mostly by deposit feeders, scavengers and harvesters (for details see Han and Pickerill, 1994c). The Nereites ichnofacies contrasts strongly with the shallow-water (shelf) Skolithos and/or Cruziana ichnofacies (Seilacher, 1967) which are characterized by deeply penetrative, vertical, permanent dwelling structures produced by suspension feeders, or vertical, inclined and horizontal crawling, feeding and resting structures produced by suspension feeders, deposit feeders and carnivores. In these latter two ichnofacies, the diversity is generally low to medium, but abundance is high. The absence of demonstrable shallow-water sedimentary structures, depositional cycles and in situ body fossils and, instead, the presence of deep-water trace-fossil associations suggest that strata of the Wapske Formation were deposited in a deep-water marine environment below storm-wave base in the presence of a slope (cf. Pickerill, 1986).

The previously described facies and facies associations undoubtedly reflect a complex depositional environment with each particular facies association representing a particular and different subenvironment within a proposed deep-water submarine fan system, including distributary channels, depositional lobes, lobe fringes, interchannels and basin plain subenvironments (Fig. 7). The location of the actual feeder channel(s) of the submarine fan(s) is still uncertain, though most likely it was to the east or southeast of the present study area, as most conglomerates are present there and what few palaeocurrent indicators there are collectively suggest a dominant west-northwest direction of turbidity current flow, consistent also with palaeogeographic considerations (see below). The general absence of coarse-grained and channelized deposits in the study area and, instead, the common occurrence of thin- to medium-bedded, laterally continuous, fine- 


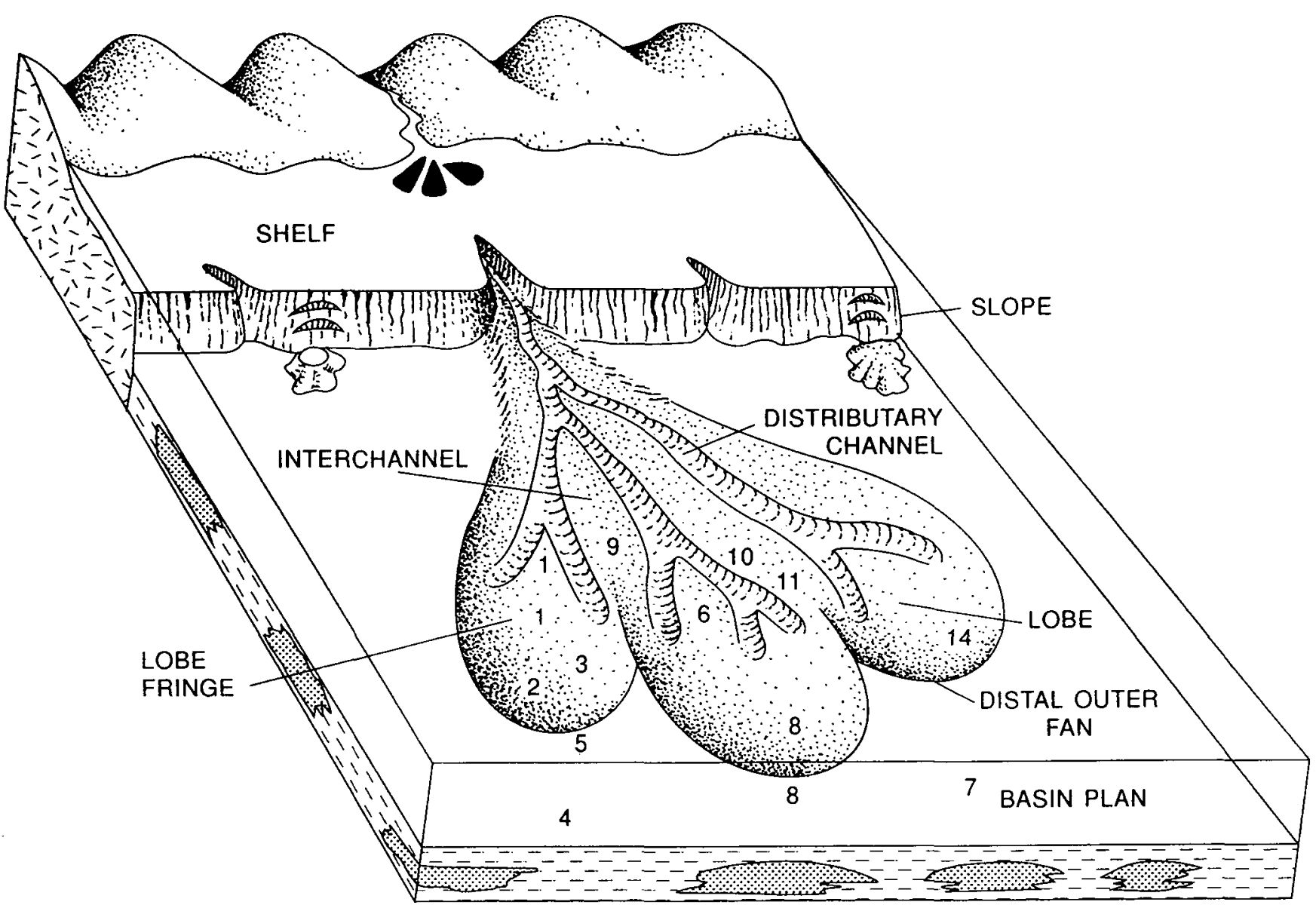

Fig. 7. Idealized deep-sea fan showing the relative positions of the facies described herein (no scale implied). Numbers refer to individual locations as detailed in Figure 2.

to medium-grained sandstones and mudstones, suggests that the depositional environment was probably that of a midor particularly, outer-fan region.

Interestingly, it should be noted that our 14 measured sections are restricted geographically to a narrow zone located approximately within the central part of the presentday Tobique Zone, and parallel to its northeasterly tectonic strike (Fig. 1). This zone is also probably approximately parallel to the presumed original depositional strike of the basin. In support of this, if the Miramichi Terrane to the southeast formed the original basin margin of what is now the Tobique Zone (see for example Hesse and Dalton, 1995, fig. 12, p. 58) and shallow marine, partly terrestrial, lithofacies in the Costigan Mountain Formation suggest it was (C. St. Peter, in litt., 1995), then the present structural trend of the Tobique Group closely coincides with the palaeodepositional trend. As a consequence, a change from shallow marine sequences in the east and southeast apparently give way to coeval deeper-water sequences, as described herein, in the west and northwest. Thus, regionally the Wapske Formation was deposited in a variety of palaeoenvironments in a basin that deepened to the west and northwest, and the sequences described herein are remnants of the deeper part of that basin.

\section{ACKnowledgements}

We wish to thank A. Gómez, R. McCulloch and D. Campbell for technical assistance, and R. Wilson and L. Fyffe, New Brunswick Department of Natural Resources and Energy, for assistance in defraying fieldwork expenses. C. St. Peter and D. Lavoie provided very helpful and constructive reviews of the initially submitted manuscript. Financial support for this research was provided by a Natural Sciences and Engineering Council of Canada operating grant to RKP, which is gratefully acknowledged.

Boucot, A.J. 1975. Evolution and extinction rate controls. Elsevier, Amsterdam, $427 \mathrm{p}$.

Boucot, A.J. and Wilson, R.A. 1994. Origin and early radiation of terebratuloid brachiopods: thoughts provoked by Prorensselaeria and Nanothyris. Journal of Paleontology, 68, pp. 1002-1025.

Bouma, A.H. 1962. Sedimentology of Some Flysch Deposits. Elsevier, New York, $168 \mathrm{p}$.

Brett, C.E., Boucot, A.J., and Jones, B. 1993. Absolute depths of Silurian benthic assemblages. Lethaia, 26, pp. 25-40.

Carter, R.M., Hicks, M.D., Norris, R.J., and Turnbull, I.M. 1978. Sedimentation patterns in an ancient arc-trench-ocean basin complex Carboniferous to Jurassic Rangitata orogen, 
New Zealand. In Sedimentation in submarine canyons, fans, and trenches. Edited by D.J. Stanley and G. Kelling. Dowden, Hutchinson \& Ross, Stroudsburg, Pennsylvania, pp. 340361.

Cazzola, C., Mutti, E., and Vigna, B. 1985. Cengio turbidite system, Italy. In Submarine fans and related turbidite systems. Edited by A.H. Bouma, W.R. Normark and N.E. Barnes. Springer-Verlag, New York, pp. 179-183.

Collnson, J.D. and Thompson, D.B. 1982. Sedimentary Structures. George Allen \& Unwin, London, 194 p.

Constable, D. 1975a. Geology of Head of Tobique-Nictau Lake, maparea K-7. New Brunswick Department of Natural Resources, Mineral Resources Branch, Plate 75-136.

1975b. Geology of Head of Mamozekel and Nipisiguit rivers, map-area K-8. New Brunswick Department of Natural Resources, Mineral Resources Branch, Plate 75-18.

Fraser, G.S. 1989. Clastic Depositional Sequences: Processes of Evolution and Principles of Interpretation. Prentice Hall, New Jersey, $459 \mathrm{p}$.

FyFFE, L.R. 1982a. Geological compilation of Andover, Carleton and Victoria counties (21 J/12). New Brunswick Department of Natural Resources, Mineral Resources Branch, Plate 84-313.

1982b. Geological compilation of Aroostook, Victoria County (21 J/13). New Brunswick Department of Natural Resources, Mineral Resources Branch, Plate 84-314.

FYFF, L.R. and FRICKER, A. 1987. Tectonostratigraphic terrane analysis of New Brunswick. Maritime Sediments and Atlantic Geology, 23, pp. 113-122.

HAN, Y. and Pickerill, R.K. 1994a. Phycodes templus isp. nov. from the Lower Devonian of northwestern New Brunswick, eastern Canada. Atlantic Geology, 30, pp. 37-46.

1994b. Taxonomic reassessment of Protovirgularia M'Coy 1850 with new examples from the Paleozoic of New Brunswick, eastern Canada. Ichnos, 3, pp. 203-212.

1994c. Palichnology of the Lower Devonian Wapske Formation, Perth-Andover-Mount Carleton region, northwestern New Brunswick, eastern Canada. Atlantic Geology, 30, pp. 217-245.

In press. Taxonomic review of the ichnogenus Helminthopsis Heer 1877 with a statistical analysis of selected ichnospecies. Ichnos, 4.

Hesse, R. and Dalton, E. 1995. Turbidite channel/overbank deposition in a Lower Devonian orogenic shale basin, Fortin Group of Gaspé Peninsula, northern Appalachians, Canada. Journal of Sedimentary Research, B65, pp. 44-60.

Howell, D.G. and Normark, W.R. 1982. Sedimentology of submarine fans. In Sandstone Depositional Environments. Edited by P.A. Scholle and D. Spearing. American Association of Petroleum Geologists, Oklahoma, pp. 365-404.

IRRINKI, R.R. 1977a. Geology of Nictau Forks of Tobique River, maparea J-9. New Brunswick Department of Natural Resources, Mineral Resources Branch, Plate 77-9.

1977b. Geology of Tobique-Bald Mountain-Riley and Neary brooks, map-area J-10. New Brunswick Department of Natural Resources, Mineral Resources Branch, Plate 77-10.

1977c. Geology of South Branch Gulquac River, map-area J12. New Brunswick Department of Natural Resources, Mineral Resources Branch, Plate 77-12.

1977d. Geology of Forks of Serpentine and Campbell rivers, map-area K-9. New Brunswick Department of Natural Resources, Mineral Resources Branch, Plate 77-13.

1977e. Geology of North Gulquac-Stewart Brook-Blue Mountain Lakes, map- area J-11. New Brunswick Department of Natural Resources, Mineral Resources Branch, Plate 77-11.

1977f. Geology of head of Serpentine River and Lake, maparea K-10. New Brunswick Department of Natural Resources,
Mineral Resources Branch, Plate 77-14.

IRRINKI, R.R. and Crouse, G.W. 1986. Geology of Sisson Branch Reservoir map area (21 O/6), New Brunswick. New Brunswick Department of Forests, Mines, and Energy, Mineral Resources Division, Map Report 86-1, 19 p.

KEMP, A.E.S. 1987. Evolution of Silurian depositional systems in the Southern Uplands, Scotland. In Marine Clastic Sedimentology, Concepts and Case Studies. Edited by J.K. Leggett and G.G. Zuffa. Graham \& Trotman, London, pp. 124-155.

MCCutcheon, S.R. and Bevier, R.L. 1990. Implications of field relations and $\mathrm{U}-\mathrm{Pb}$ geochemistry for the age of gold mineralization and timing of Acadian deformation in northern New Brunswick. Atlantic Geology, 26, pp. 237-246.

Mutri, E. 1977. Distinctive thin-bedded turbidite facies and related depositional environments in the Eocene Hecho Group (Southcentral Pyrenees, Spain). Sedimentology, 24, pp. 107-131.

MutTI, E. and Normark, W.R. 1987. Comparing examples of modern and ancient turbidite systems: problems and concepts. In Marine Clastic Sedimentology, Concepts and Case Studies. Edited by J.K. Leggett and G.G. Zuffa. Graham \& Trotman, London, pp. 1-38.

Mutri, E. and Ricci Lucchi, F. 1972. Le torbiditi dell' Appennino settentrionole: introduzione all'analisi di facies. Memories della Societa Geologica Italiana, 11, pp. 161-199.

Nelson, C.H. and KurM, V.D. 1973. Submarine fans and channels. In Turbidites and deep-water sedimentation. Edited by G.V. Middleton and A.H. Bouma. Society of Economic Paleontologists and Mineralogists, Pacific Section, Short Course, Anaheim, California, pp. 39-78.

NiLSEN, T.H. 1984a. Turbidite facies. In Modern and ancient deep-sea fan sedimentation. Edited by C.H. Nelson and T.H. Nilsen. Society of Economic Paleontologists and Mineralogists Short Course, 14, pp. 170-196.

1984b. Turbidite facies association. In Modern and ancient deep-sea fan sedimentation. Edited by C.H. Nelson and T.H. Nilsen. Society of Economic Paleontologists and Mineralogists Short Course, 14, pp. 197-300.

1985. Butano turbidite system, California. In Submarine fans and related turbidite systems. Edited by A.H. Bouma, W.R. Normark and N.E. Barnes. Springer-Verlag, New York, pp. 173178.

Normark, W.R. 1970. Growth patterns of deep-sea fans. American Association of Petroleum Geologists Bulletin, 54, pp. 2170-2195.

PickeriLL, R.K. 1986. Stratigraphy, sedimentology and structural analysis of the geology of the Tobique Reserve Lands with an economic assessment of its geologic resources. Unpublished Report to the Department of Indian and Northern Affairs, Ottawa, Ontario, $61 \mathrm{p}$.

- 1991. The trace fossil Neonereites multiserialis Pickerill and Harland, 1988 from the Devonian Wapske Formation, northwest New Brunswick. Atlantic Geology, 27, pp. 119-126.

Pickerill, R.K. and Brenchley, P.J. 1991. Paleoscene 12. Benthic macrofossils as paleoenvironmental indicators in marine siliciclastic facies. Geoscience Canada, 18, pp. 119-138.

Pickering, K.T. 1981. Two types of outer fan lobe sequence, from the late Precambrian Kongsfjord Formation submarine fan, Finnmark, North Norway. Journal of Sedimentary Petrology, 51, pp. 12771286.

1982a. A Precambrian upper basin-slope and prodelta in northeast Finnmark, North Norway - a possible ancient upper continental slope. Journal of Sedimentary Petrology, 52, pp. 171-186.

__ 1982b. Middle-fan deposits from the late Precambrian Kongsfjord Formation submarine fan, northeast Finnmark, northern Norway. Sedimentary Geology, 33, pp. 79-110.

1984. Facies, facies-associations and sediment transport/deposition processes in a late Precambrian upper basin-slope/pro-delta, 
Finnmark, N. Norway. In Fine-grained Sediments: Deep-Water Processes and Facies. Edited by D.A.V. Stow and D.J.W. Piper. Geological Society of London, Special Publication, 15, pp. 343362.

1985. Kongsfjord turbidite system, Norway. In Submarine Fans and Related Turbidite Systems. Edited by A.H. Bouma, W.R. Normark and N.E. Barnes. Springer-Verlag, New York, pp. 237244.

Pickering, K.T., Stow, D., Watson, M., and Hiscott, R. 1986. Deepwater facies, processes and models: a review and classification scheme for modern and ancient sediments. Earth-Science Reviews, 23, pp. 76-174.

ReAdING, H.G. 1986. Facies. In Sedimentary Environments and Facies. Edited by H.G. Reading. H.G. Blackwell, Oxford, pp. 4-19.

Ricci Lucchi, F. 1975a. Depositional cycles in two turbidite formations of northern Apennines. Journal of Sedimentary Petrology, 45 , pp. 3-43.

1975b. Miocene paleogeography and basin analysis in the Periadriatic Apennines. In Geology of Italy. Edited by C. Squyres. Petroleum Exploration Society of Libya, Tripoli, pp. 129-236.

RoY, D.C. and MeNCHER, E. 1976. Ordovician and Silurian stratigraphy of northeastern Aroostook County, Maine. Geological Society of America, Memoir 148, pp. 25-52.

SEILACHER, A. 1967. Bathymetry of trace fossils. Marine Geology, 5, pp. $413-428$.

Shanmugam, G., Lehtonen, L.R., Straume, T., Syvertsen, S.E., Hodgkinson, R.J., and Skibeli, M. 1994. Slump and debris-flow dominated upper slope facies in the Cretaceous of the Norwegian and northern North Seas $\left(61-67^{\circ} \mathrm{N}\right)$ : implications for sand distribution. Bulletin of the American Association of Petroleum Geologists, 78, pp. 910-937.

SkINNER, R. 1971. Plaster Rock map-area, New Brunswick. In Report of Activities, Part A, April to October. Geological Survey of Canada, Paper 71-1, pp. 13-16.

- 1972. Juniper (east half) map-area, New Brunswick. In Report of Activities, Part A, April to October. Geological Survey of Canada, Paper 72-1, pp. 11-14.

1982. Geology of the Plaster Rock (east half) map area, New Brunswick. Geological Survey of Canada, Paper 81-8, 16 p.

St. Peter, C. 1978a. Geology of parts of Restigouche, Victoria, and Madawaska counties, northwestern New Brunswick. New Brunswick Department of Natural Resources, Mineral Resources
Branch, Report of Investigation 17,69 p.

1978b. Geology of head of Wapske River, map area J-13 (21 J/

14). New Brunswick Department of Natural Resources, Mineral Resources Branch, Map Report 78-1, 24 p.

1979. Geology of Wapske-Odell River-Arthurette region, New Brunswick, map areas I-13, I-14, H-14 (parts of $21 \mathrm{~J} / 11,21 \mathrm{~J} / 12$, $21 \mathrm{~J} / 13,21 \mathrm{~J} / 14$ ). New Brunswick Department of Natural Resources, Mineral Resources Branch, Map Report 79-2, 32 p.

- 1981. Geology of North Branch Southwest Miramichi River, map areas J-14, J-15, J-16 (parts of $21 \mathrm{~J} / 11 \mathrm{E}, 21 \mathrm{~J} / 14 \mathrm{E}$ ). New Brunswick Department of Natural Resources, Mineral Resources Branch, Map Report 80-1, 61 p.

1982. Geology of Juniper-Knowlesville-Carlisle area, map areas I-16, I-17, I-18 (parts of $21, \mathrm{~J} / 11,21 \mathrm{~J} / 6$ ). New Brunswick Department of Natural Resources, Mineral Resources Branch, Map Report 82-1, 82 p.

WALKER, R.G. 1967. Turbidite sedimentary structures and their relationship to proximal and distal depositional environments. Journal of Sedimentary Petrology, 37, pp. 25-43.

1973. Mopping up the turbidite mess. In Evolving concepts in sedimentology. Edited by R.N. Ginsburg. The Johns Hopkins Press, Baltimore, pp. 1-37.

1984. Turbidites and associated coarse clastic deposits. In Facies Models. Geoscience Canada, Reprint Series 1. Edited by R.G. Walker. Ainsworth, Kitchener, pp. 171-188.

1992. Turbidites and submarine fans. In Facies Models: response to sea level change. Edited by R.G. Walker and N.P. James. Geological Association of Canada, Ainsworth, Kitchener, pp. 239263.

WALKER, R.G. and MutTI, E. 1973. Turbidite facies and facies associations. In Turbidites and deep-water sedimentation. Edited by G.V. Middleton and A.H. Bouma. Society of Economic Paleontologists and Mineralogists, Pacific Section, Short Course, Anaheim, California, pp. 119-157.

Williams, H. 1983. Appalachian suspect terranes. In Contributions to the Tectonics and Geophysics of Mountain Ranges. Edited by R.D. Hatcher, Jr., H. Williams and I. Zietz. Geological Society of America, Memoir 158, pp. 33-53.

Wilson, R.A. 1990. Geology of New Denmark-Salmon River area Victoria County, New Brunswick (parts of NTS J/13, 21 J/14, 21O/ 3, 210/4). New Brunswick Department of Natural Resources, Minerals and Energy Division, Report of Investigation 23, 67 p. 